\title{
Seismic activity on the territory of Slovakia in 2016
}

\author{
Róbert KYSEL ${ }^{1,2, *}$, Andrej CIPCIAR ${ }^{1,2}$, Zuzana CHOVANOVÁ ${ }^{1,3}$, \\ Kristián CSICSAY ${ }^{1}$, Lucia FOJTÍKOVÁ ${ }^{1,4}$, Martin GÁLIS ${ }^{1,2}$, \\ Miriam KRISTEKOVÁ 1,2 \\ ${ }^{1}$ Earth Science Institute of the Slovak Academy of Sciences, \\ Dúbravská cesta 9, P. O. Box 106, 84005 Bratislava, Slovak Republic \\ ${ }^{2}$ Faculty of Mathematics, Physics and Informatics, Comenius University in Bratislava, \\ Mlynská dolina, 84248 Bratislava, Slovak Republic \\ ${ }^{3}$ Faculty of Natural Sciences, Comenius University in Bratislava, \\ Mlynská dolina, Ilkovičova 6, 84215 Bratislava, Slovak Republic \\ ${ }^{4}$ Institute of Rock Structure and Mechanics of the Czech Academy of Sciences, \\ V Holesovickach 94/41, 182 09, Prague 8, Czech Republic
}

\begin{abstract}
The National Network of Seismic Stations of Slovakia (NNSS) consists of eight short period and five broadband permanent seismic stations and a data centre located at the Earth Science Institute of the Slovak Academy of Sciences (ESI SAS). The NNSS recorded and detected 10888 seismic events from all epicentral distances in 2016. Totally 87 earthquakes originated in the territory of Slovakia in 2016. This paper provides basic information on the configuration of the NNSS, routine data processing, seismic activity on the territory of Slovakia in 2016 as well as macroseismic observations collected in 2016 .
\end{abstract}

Key words: Slovakia, National Network of Seismic Stations, seismicity, macroseismic observations

\section{Introduction}

The seismic activity on the territory of Slovakia and adjacent areas has been reported on the daily basis by the so-called Seismo Reports published on the web sites of the Department of Seismology, ESI SAS http://www.seismo logy.sk/Seismo_Reports/reports.html and in annual reports as a part of the project Partial monitoring system - Geological factors (Liščák et al., 2017) which is solved with a contract between ESI SAS and State Geological Institute of Dionýz Štúr. The aim of this paper is to provide a quick

\footnotetext{
*corresponding author: e-mail: robert.kysel@savba.sk
} 
overview of earthquakes which originated on the territory of Slovakia or were macroseismically felt on the territory of Slovakia in 2016.

\section{Seismic stations operating in 2016}

The seismic monitoring of the Slovak territory is provided by the NNSS operated by the ESI SAS (ESI SAS, 2004), Local Seismic Network in Eastern Slovakia operated by the Faculty of Mathematics, Physics and Informatics of the Comenius University in Bratislava and local network of seismic stations around NPPs Jaslovské Bohunice and Mochovce operated by Progseis Ltd. company. The networks of seismic stations cooperate and the exchange of data is on the regular basis. The positions of the seismic stations on the territory of Slovakia are shown in Fig. 1.

In 2016 the NNSS consisted of thirteen permanent seismic stations, from which eight are short period and five are broadband. Broadband stations are: Červenica (CRVS), Kolonické sedlo (KOLS), Modra (MODS), Vyhne (VYHS) and Železná studnička (ZST). Short period stations are: Hurbanovo (HRB), Iža (SRO1), Kečovo (KECS), Liptovská Anna (LANS), Moča (SRO2), Stebnícka Huta (STHS) and Šrobárová (SRO). The HRB

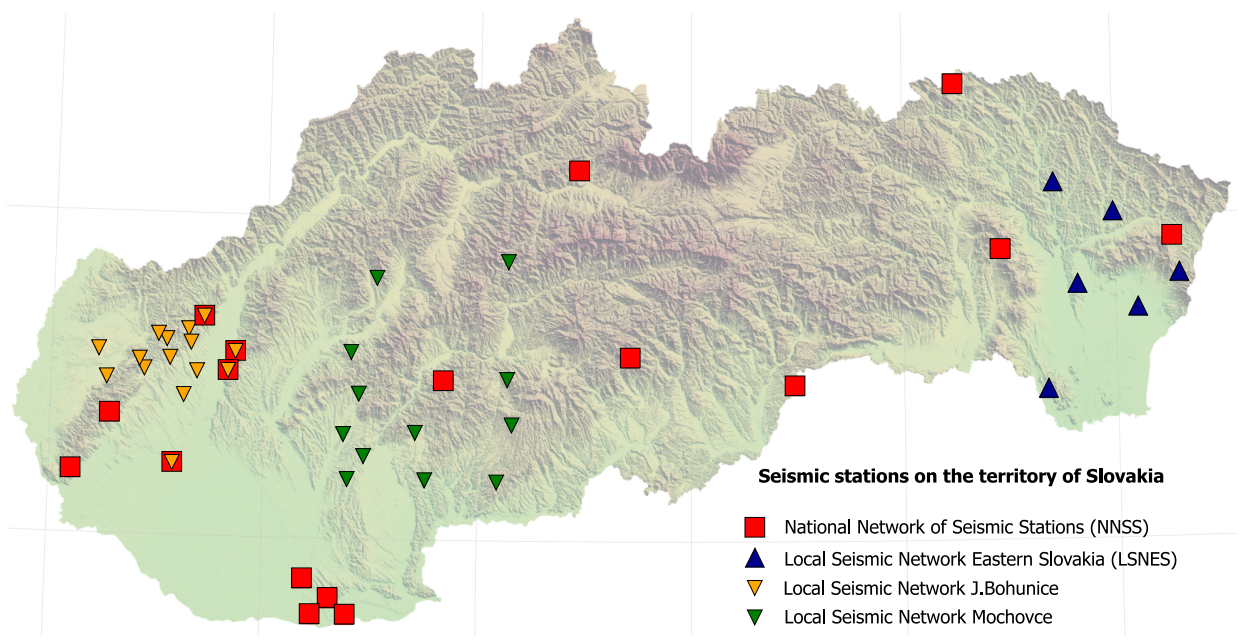

Fig. 1. Seismic stations operational on the territory of Slovakia in 2016. 
is the oldest NNSS seismic station that has been in operation since 1909 (Pajdušák, 1997). In 2016, the seismic station Izabela (IZAB) has been added to the NNSS as a new permanent short period seismic station. This station has been jointly operated by ESI SAS and Progseis Ltd. company. In this year the seismic station MODS has been upgraded with a 6-channel 32bit digitizer and an EpiSensor has been installed. The NNSS permanent seismic stations and their instrumentation are summarized in Table 1. More details can be found on the web page http://www.seismology.sk/National _Network.

Table 1. Equipment of seismic stations of the NNSS operating in 2016.

\begin{tabular}{|c|c|c|c|c|c|c|c|c|}
\hline Station & $\begin{array}{c}\text { ISC } \\
\text { code }\end{array}$ & $\begin{array}{c}\text { Lat. } \\
{\left[{ }^{\circ} \mathbf{N}\right]}\end{array}$ & $\begin{array}{c}\text { Long. } \\
{\left[{ }^{\circ} \mathbf{E}\right]}\end{array}$ & $\begin{array}{c}\text { Alt. } \\
{[\mathbf{m}]}\end{array}$ & Sensor & DAS & $\begin{array}{c}\text { Sampl. } \\
\text { freq. }\end{array}$ & $\begin{array}{c}\text { Data } \\
\text { format }\end{array}$ \\
\hline $\begin{array}{c}\text { Bratislava } \\
\text { Zel. Studnička }\end{array}$ & ZST & 48.196 & 17.102 & 250 & $3 \times$ SKD & Wave24 & $100 /$ sec & mSEED \\
\hline Červenica & CRVS & 48.902 & 21.461 & 476 & STS-2 & Wave24 & $100 /$ sec & mSEED \\
\hline Vyhne & VYHS & 48.493 & 18.836 & 450 & STS-2 & Wave24 & $100 /$ sec & mSEED \\
\hline Modra-Piesok & MODS & 48.373 & 17.277 & 520 & STS-2 & Wave32 & $100 /$ sec & mSEED \\
\hline Hurbanovo & HRB & 47.873 & 18.192 & 115 & $\begin{array}{c}2 \times \\
\text { Mainka }\end{array}$ & Analog & - & $\begin{array}{c}\text { smoked } \\
\text { paper }\end{array}$ \\
\hline Izabela & IZAB & 48.569 & 19.713 & 450 & $3 \times$ SM3 & Wave24 & $100 /$ sec & mSEED \\
\hline Iža & SRO1 & 47.7622 & 18.2328 & 111 & ViGeo & Gaia & $100 /$ sec & mSEED \\
\hline Kečovo & KECS & 48.483 & 20.486 & 345 & LE3D & Wave24 & $100 /$ sec & mSEED \\
\hline Kolonické sedlo & KOLS & 48.933 & 22.273 & 460 & $\begin{array}{c}\text { Guralp- } \\
6 \text { T-30s }\end{array}$ & Wave32 & $100 /$ sec & mSEED \\
\hline Liptovská Anna & LANS & 49.151 & 19.468 & 710 & LE3D & SEMS & $100 /$ sec & mSEED \\
\hline Moča & SRO2 & 47.763 & 18.394 & 109 & $\begin{array}{c}\text { Guralp- } \\
40 T-1 s\end{array}$ & Wave24 & $100 /$ sec & mSEED \\
\hline Stebnícka Huta & STHS & 49.417 & 21.244 & 534 & LE3D & Wave24 & $100 /$ sec & mSEED \\
\hline Šrobárová & SRO & 47.813 & 18.313 & 150 & $\begin{array}{c}3 \times \\
\text { SKM-3 }\end{array}$ & Wave24 & $100 /$ sec & mSEED \\
\hline
\end{tabular}

Four additional short period seismic stations has been operated on the jointly bases of ESI SAS and the other institutions. The seismic stations Banka (BAN), Podolie (POD) and Jalšové (JAL) located in the Little Carpathians has been operated in cooperation with Progseis Ltd. company and the Institute of Rock Structure and Mechanics of the Czech Academy of Sciences (IRSM CAS) (Fojtiková et al., 2015). The seismic station Pusté Úlany (PULA) has been operated in cooperation with the IRSM CAS. These stations have been installed as temporary seismic stations. 


\section{Data processing}

Digital data from all NNSS stations (except the analog seismic station HRB) are transfered in real-time to the data centre at the ESI SAS either by the internet or satelite telemetry. Software package SeisComp3 (Weber et al., 2007) and SeedLink server are used for data acquisition and exchange.

Beside observations from the NNSS stations the data centre at ESI SAS also use the data from the above mentioned local networks of seismic stations in Slovakia and observations from networks of neighbouring countries: Austrian Seismic Network (ZAMG - Zentralanstalt für Meterologie und Geodynamik, 1987), Czech Regional Seismic Network (Institute of Geophysics, Academy of Sciences of the Czech Republic, 1973), Hungarian National Seismological Network (Kövesligethy Radó Seismological Observatory, 1992), Local seismological network for monitoring NPP Dukovany (Institute of Physics of the Earth Masaryk University, 2014), GEOFON Seismic Network (GEOFON Data Center, 1993), Polish Seismological Network. These stations forms a so-called Regional Virtual Network of ESI SAS that consists of approximately 55 seismic stations.

Routine analysis of the digital recordings at the ESI SAS has been performed by the Unix package Seismic handler (Stammler, 1993). Interactive locations of seismic events within Seismic Handler are performed by external program LocSat. The collected digital observations are manually processed on the daily basis. The epicentre locations are based on the IASPI91 traveltime curves. Local magnitudes has been determined from the maximum vertical trace amplitudes of Sg waves, using the pre-defined Seismic Handler formula for local events. Continuous raw seismic data from the NNSS are stored in a local archive and seismic data interpretations (together with information on equipment of stations) are stored in a web accessible database.

\section{Seismic activity in 2016}

The NNSS analyzed 10888 local, regional and teleseismic events in 2016. More than 40600 seismic phases were determined. Seismic events identified as quarry blasts were excluded from further processing and were not 
included in the event statistics. All events recorded by the NNSS and analyses at the data centre at ESI SAS has been reported in the so-called Seismo Reports and published on the above mentioned web sites of the Department of Seismology, ESI SAS.

Altogether 87 seismic events located by the NNSS originated in the territory of Slovakia in 2016 (Fig. 2). Known quarry blasts are not included in this number. 28 earthquakes reached local magnitude 1.0 or more and are listed in Table 2. The strongest earthquake was detected on April 18 at 13:20 UTC with local magnitude $M_{L} 1.9$.

The seismicity of the Slovak territory is dominated by the Little Carpathians and Komárno seismic source zones. The strongest earthquake in the Little Carpathians source zone was detected on the December 12 at 21:43 UTC with local magnitude $M_{L}$ 1.4. The strongest earthquake in the Komárno source zone was detected on the June 23 at 21:52 UTC with local magnitude $M_{L}$ 1.4. Although the low level of seismic activity from the last decades remained unchanged in 2016, these two source zones remains of the primary interest for the monitoring of seismic activity within the territory of Slovakia.

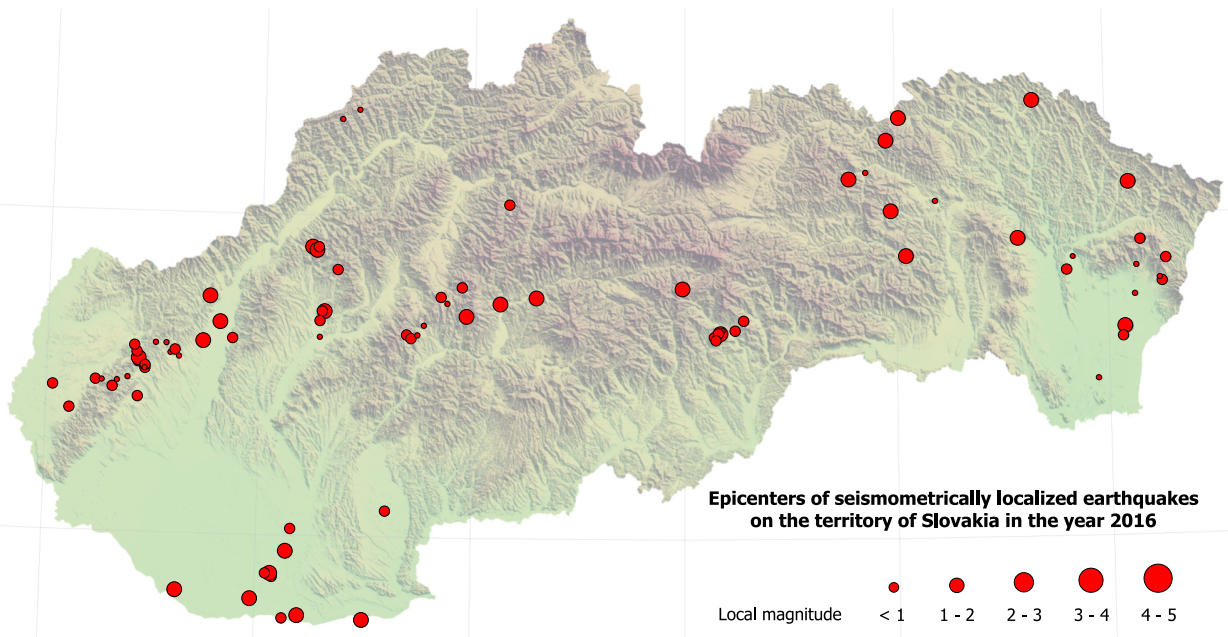

Fig. 2. Map of epicentres of local earthquakes originated on the territory of Slovakia in 2016. Diameters of the circles are proportional to local magnitudes. 
Table 2. List of earthquakes originated on the territory of Slovakia in 2016 with $M_{L} \geq 1.0$.

\begin{tabular}{|c|c|c|c|c|c|c|c|}
\hline$\frac{\text { Date }}{[\mathbf{Y Y Y Y}-\mathbf{M M}-\mathrm{DD}]}$ & $\begin{array}{c}\text { Origin Time } \\
\text { (UTC) } \\
\text { [HH:MM:SS] }\end{array}$ & $\begin{array}{l}\text { Lat. } \\
{\left[{ }^{\circ} \mathbf{N}\right]}\end{array}$ & $\begin{array}{l}\text { Lon. } \\
{\left[{ }^{\circ} \mathbf{E}\right]}\end{array}$ & $\begin{array}{c}\text { Depth } \\
{[\mathrm{km}]}\end{array}$ & $\begin{array}{c}M_{L} \\
\text { [NNSS] }\end{array}$ & $\begin{array}{c}\boldsymbol{I}_{0} \\
{\left[{ }^{\circ} \mathbf{E M S}\right]}\end{array}$ & Region \\
\hline 2016-01-24 & $22: 18: 56.83$ & 48.64 & 20.17 & 0 & 1.6 & & $\begin{array}{l}\text { Revúca } \\
\text { Highlands }\end{array}$ \\
\hline 2016-02-13 & 21:34:17.90 & 48.75 & 19.30 & 0 & 1.0 & & $\begin{array}{l}\text { Upper Hron } \\
\text { River region }\end{array}$ \\
\hline 2016-03-31 & 09:10:51.76 & 47.74 & 18.50 & 0 & 1.2 & & $\begin{array}{c}\text { Šamorín - } \\
\text { Komárno - } \\
\text { Štúrovo }\end{array}$ \\
\hline 2016-04-15 & $12: 56: 16.97$ & 48.65 & 22.08 & 2.4 & 1.5 & & $\begin{array}{l}\text { Eastern Slovak } \\
\text { Lowland }\end{array}$ \\
\hline 2016-04-15 & $17: 30: 25.25$ & 48.70 & 18.30 & 0.2 & 1.0 & & Strážov Mts. \\
\hline 2016-04-18 & 13:20:39.86 & 49.24 & 20.96 & 0 & 1.9 & & Čergov Mts. \\
\hline 2016-05-03 & 05:12:59.03 & 47.88 & 18.07 & 0 & 1.0 & & $\begin{array}{l}\text { Šamorín - } \\
\text { Komárno - } \\
\text { Štúrovo }\end{array}$ \\
\hline 2016-05-05 & $08: 18: 20.67$ & 49.36 & 21.66 & 21.6 & 1.6 & & $\begin{array}{c}\text { Laborec } \\
\text { Highlands }\end{array}$ \\
\hline 2016-05-29 & $08: 26: 21.82$ & 47.80 & 17.98 & 1.5 & 1.1 & & $\begin{array}{l}\text { Šamorín - } \\
\text { Komárno - } \\
\text { Štúrovo }\end{array}$ \\
\hline 2016-06-01 & 05:34:50.91 & 48.54 & 17.43 & 1.9 & 1.1 & & $\begin{array}{c}\text { Little } \\
\text { Carpathians }\end{array}$ \\
\hline 2016-06-10 & $07: 43: 05.26$ & 48.88 & 21.05 & 0 & 1.1 & & Šariš \\
\hline 2016-06-23 & $21: 52: 19.25$ & 47.75 & 18.20 & 0 & 1.4 & & $\begin{array}{l}\text { Šamorín - } \\
\text { Komárno - } \\
\text { Štúrovo }\end{array}$ \\
\hline 2016-06-24 & $08: 44: 43.24$ & 48.74 & 17.76 & 8.3 & 1.3 & 3 & $\begin{array}{c}\text { Little } \\
\text { Carpathians }\end{array}$ \\
\hline 2016-06-25 & 00:33:01.20 & 48.73 & 19.13 & 0 & 1.1 & & $\begin{array}{c}\text { Banská Bystrica } \\
\text { region }\end{array}$ \\
\hline 2016-06-30 & $19: 35: 51.24$ & 48.60 & 17.73 & 2 & 1.1 & & $\begin{array}{c}\text { Little } \\
\text { Carpathians }\end{array}$ \\
\hline 2016-07-11 & $10: 37: 40.28$ & 49.31 & 21.02 & 4.2 & 1.6 & & Čergov Mts. \\
\hline 2016-07-26 & $10: 46: 55.58$ & 48.93 & 21.58 & 6 & 1.1 & & Slanské Hills \\
\hline 2016-07-30 & 09:36:11.71 & 49.10 & 22.11 & 0 & 1.5 & & $\begin{array}{c}\text { Laborec } \\
\text { Highlands }\end{array}$ \\
\hline 2016-08-07 & $19: 20: 12.61$ & 48.69 & 18.97 & 0 & 1.4 & & Kremnica Mts. \\
\hline $2016-08-13$ & $22: 30: 30.47$ & 48.90 & 18.24 & 1 & 1.3 & & Strážov Mts. \\
\hline
\end{tabular}


Table 2. Continued from the previous page.

\begin{tabular}{|c|c|c|c|c|c|c|c|}
\hline $\begin{array}{c}\text { Date } \\
{[\text { YYYY-MM-DD }]}\end{array}$ & $\begin{array}{c}\text { Origin Time } \\
\text { (UTC) } \\
\text { [HH:MM:SS] }\end{array}$ & $\begin{array}{l}\text { Lat. } \\
{\left[{ }^{\circ} \mathbf{N}\right]}\end{array}$ & $\begin{array}{l}\text { Lon. } \\
{\left[{ }^{\circ} \mathbf{E}\right]}\end{array}$ & $\begin{array}{c}\text { Depth } \\
{[\mathrm{km}]}\end{array}$ & $\begin{array}{c}M_{L} \\
{[\mathrm{NNSS}]}\end{array}$ & $\begin{array}{c}\boldsymbol{I}_{0} \\
{\left[{ }^{\circ} \mathbf{E M S}\right]}\end{array}$ & Region \\
\hline 2016-08-25 & $04: 58: 42.28$ & 47.95 & 18.14 & 0 & 1.3 & & $\begin{array}{l}\text { Šamorín - } \\
\text { Komárno - } \\
\text { Štúrovo }\end{array}$ \\
\hline 2016-08-26 & $23: 50: 14.51$ & 48.89 & 18.26 & 2.4 & 1.1 & & Strážov Mts. \\
\hline 2016-09-29 & 05:58:11.72 & 48.78 & 19.99 & 0 & 1.3 & & Muráň Plateau \\
\hline 2016-10-09 & $20: 45: 11.06$ & 47.82 & 17.63 & 0 & 1.4 & & $\begin{array}{l}\text { Šamorín - } \\
\text { Komárno - } \\
\text { Štúrovo }\end{array}$ \\
\hline 2016-10-17 & $11: 39: 51.89$ & 49.02 & 20.98 & 7.1 & 1.6 & & Šariš \\
\hline 2016-11-25 & $09: 29: 47.57$ & 49.12 & 20.78 & 0 & 1.4 & & Levoča Mts. \\
\hline 2016-12-12 & $21: 43: 31.28$ & 48.66 & 17.81 & 3.7 & 1.4 & & $\begin{array}{c}\text { Little } \\
\text { Carpathians }\end{array}$ \\
\hline
\end{tabular}

\section{Macroseismic observations}

Two earthquakes were macroseismically felt on the territory of Slovakia in 2016, one with the epicentre in Austria and one with the epicentre on the territory of Slovakia (Table 3). These two earthquakes were also seismometrically observed and processed. Intensities were estimated by the European Macroseismic Scale 1998 (EMS-98) introduced by Grünthal (1998).

The earthquake on April 25 at 10:28 UTC with epicentre near Vienna, Austria and local magnitude 4.1 was macroseismically felt on 9 locations within the territory of Slovakia (Table 4). 12 macroseismic questionnaires were filled. People reported weak trembling or shaking and acoustic effects

Table 3. List of macroseismically observed earthquakes on the territory of Slovakia in 2016.

\begin{tabular}{|c|c|c|c|c|c|c|c|}
\hline $\begin{array}{c}\text { Date } \\
\text { [YYYY-MM-DD] }]\end{array}$ & $\begin{array}{c}\text { Origin Time } \\
\text { (UTC) } \\
\text { [HH:MM:SS] }\end{array}$ & $\begin{array}{c}\text { Lat. } \\
{\left[{ }^{\circ} \mathbf{N}\right]}\end{array}$ & $\begin{array}{c}\text { Lon. } \\
{\left[{ }^{\circ} \mathbf{E}\right]}\end{array}$ & $\begin{array}{c}\text { Depth } \\
{[\mathbf{k m}]}\end{array}$ & $\begin{array}{c}\boldsymbol{M}_{\boldsymbol{L}} \\
{[\mathbf{N N S}]}\end{array}$ & $\begin{array}{c}\boldsymbol{I}_{\mathbf{0}} \\
{\left[{ }^{\circ} \mathbf{E M S}\right]}\end{array}$ & Region \\
\hline $2016-04-25$ & $10: 28: 23.6$ & 48.02 & 16.16 & 14.1 & 4.0 & $5-6$ & Austria \\
\hline $2016-06-24$ & $08: 44: 43.2$ & 48.74 & 17.76 & 8.3 & 1.3 & 3 & $\begin{array}{c}\text { Little } \\
\text { Carpathians }\end{array}$ \\
\hline
\end{tabular}


Table 4. Macroseismic observations for April 25, 2016 earthquake, 10:28 UTC.

\begin{tabular}{|l|c|c|c|c|}
\hline Locality & $\begin{array}{c}\text { Lat. } \\
{\left[{ }^{\circ} \mathbf{N}\right]}\end{array}$ & $\begin{array}{c}\text { Lon. } \\
{\left[{ }^{\circ} \mathbf{E}\right]}\end{array}$ & $\begin{array}{c}\text { No. of } \\
\text { questionnaires }\end{array}$ & $\begin{array}{c}\text { I } \\
{\left[{ }^{\circ} \text { EMS-98 }\right]}\end{array}$ \\
\hline Bratislava 5 & 48.111 & 17.112 & 3 & 3 \\
\hline Bratislava 4 & 48.159 & 17.052 & 2 & 3 \\
\hline Bratislava 1 & 48.147 & 17.102 & 1 & 3 \\
\hline Galanta & 48.198 & 17.734 & 1 & 3 \\
\hline Kolín̆any & 48.351 & 18.229 & 1 & 3 \\
\hline Orechová Potôn̆ & 48.036 & 17.564 & 1 & 3 \\
\hline Pezinok & 48.298 & 17.270 & 1 & felt \\
\hline Modrý Kameñ & 48.248 & 19.324 & 1 & felt \\
\hline Vel'ká Lomnica & 49.112 & 20.354 & 1 & \\
\hline
\end{tabular}

- rumbling. The maximum intensity on the territory of Slovakia was determined at $3^{\circ}$ EMS-98.

The earthquake on June 24 at 8:44 UTC with epicentre in the northern part of Little Carpathians (near Nové Mesto nad Váhom) and local magnitude 1.3 was macroseismically felt on 1 location (Table 5). 2 macroseimic questionnaires were filled. The event was described as a light trembling. The epicentral intensity was determined at $3^{\circ}$ EMS-98.

Table 5. Macroseismic observations for June 24, 2016 earthquake, 8:44 UTC.

\begin{tabular}{|l|c|c|c|c|}
\hline Locality & $\begin{array}{c}\text { Lat. } \\
{\left[{ }^{\circ} \mathbf{N}\right]}\end{array}$ & $\begin{array}{c}\text { Lon. } \\
{\left[{ }^{\circ} \mathbf{E}\right]}\end{array}$ & $\begin{array}{c}\text { No. of } \\
\text { questionnaires }\end{array}$ & $\begin{array}{c}\boldsymbol{I} \\
{\left[{ }^{\circ} \mathbf{E M S - 9 8}\right]}\end{array}$ \\
\hline $\begin{array}{l}\text { Nové Mesto nad } \\
\text { Váhom }\end{array}$ & 48.758 & 17.829 & 2 & 3 \\
\hline
\end{tabular}

\section{Conclusion and discussion}

The NNSS is operated by the ESI SAS, Bratislava. In 2016 a new seismic station Izabela was added to the NNSS and an EpiSensor was installed in the Little Carpathians source zone in seismic station MODS. Data from all stations (except station HRB) are transferred in real-time to the data centre at Bratislava. Data processing and routine analysis are performed digitally by interactive seismological software Seismic Handler. Digital data 
are accessible both on-line and off-line in standard data format. So-called Seismo Reports of seismic events recorded by NNSS are published on the web page of the ESI SAS http://www.seismology.sk/Seismo Reports/repor ts.html.

Epicentres and local magnitudes were determined for 87 earthquakes originated in the territory of Slovakia in 2016. Weak seismic activity was recorded from several seismic source zones: Little Carpathians, Komárno, Strážov Mts., Čergov Mts., Revúca Highlands and Vihorlat Mts.

Acknowledgements. The authors have been supported by the Slovak Foundation Grant VEGA 2/0188/15 and The Slovak Research and Development Agency Grant APVV-16-0146.

\section{References}

ESI SAS (Earth Science Institute of the Slovak Academy of Sciences), 2004: National Network of Seismic Stations of Slovakia. Deutsches GeoForschungsZentrum GFZ, Other/Seismic Network, doi: 10.14470/FX099882.

Fojtíková L., Kristeková M., Málek J., Sokos E., Csicsay K., Záhradník J., 2015: Quantifying capability of a local seismic network in terms of locations and focal mechanism solutions of weak earthquakes. Journal of Seismology, 20, 1, 93-106, doi : 10.1007/ s10950-015-9512-1.

GEOFON Data Center, 1993: GEOFON Seismic Network. Deutsches GeoForschungsZentrum GFZ, Other/Seismic Network, doi : 10.14470/TR560404.

Grünthal G. (Ed.), 1998: European Macroseismic Scale 1998 EMS-98. Cahiers du Centre Européen de Géodynamique et de Séismologie, 15, Luxembourg, 101 p., http://gfz public.gfz-potsdam.de/pubman/item/escidoc: 56109 .

Institute of Geophysics, Academy of Sciences of the Czech Republic, 1973: Czech Regional Seismic Network. International Federation of Digital Seismograph Networks, Other/Seismic Network, doi: 10.7914/SN/CZ.

Institute of Physics of the Earth Masaryk University (Czech), 2014: IPE_EDU. International Federation of Digital Seismograph Networks, Other/Seismic Network, doi : 10.7914/SN/D1.

Kövesligethy Radó Seismological Observatory (Geodetic and Geophysical Institute, Research Centre for Astronomy and Earth Sciences, Hungarian Academy of Sciences (MTA CSFK GGI KRSZO)), 1992: Hungarian National Seismological Network. Deutsches GeoForschungsZentrum GFZ, Other/Seismic Network, doi : 10.14470/UH 028726 . 
Liščák P., Petro L., Papčo J., Cipciar A., Csicsay K., Kristeková M., Bednárik M., Briestenský M., Bella P., Správa slovenských jaskýň, 2017: Partial Monitoring System - Geological Factors, Subsystem 02: Tectonic and seismic activity of the territory, Geological work number 207, Report for 2016 (Čiastkový monitorovací systém - Geologické faktory, Podsystém 02: Tektonická a seizmická aktivita, číslo geologickej úlohy 207, správa za obdobie: rok 2016), State Geological Institute of Dionýz Štúr, Regional centre Košice, 36, http://dionysos.gssr.sk/cmsgf/files/ Hodn_monitor_2016/02_Tektonicka_aktivita_2016.pdf (in Slovak).

Local Seismic Network of Eastern Slovakia. Faculty of Mathematics, Physics of the Earth and Informatics, Comenius University, html://www.fyzikazeme.sk/mainpage/ind ex_en.htm.

Pajdušák P., 1997: Historical seismic instruments at the stations Hurbanovo (HRB) and Skalnaté pleso (SPC) of Slovakia. Cahiers du Centre Européen de Géodynamique et de Séismologie, 13, 49-60.

Polish Seismological Network (PLSN), Institute of Geophysics Polish Academy of Sciences, https://www.igf.edu.pl/stacje-en.php.

Stammler K., 1993: Seismichandler-Programmable multichannel data handler for interactive and automatic processing of seismological analyses. Computers \& Geosciences, 19, 2, 135-140, doi : 10.1016/0098-3004(93)90110-Q.

Weber B., Becker J., Hanka W., Heinloo A., Hoffmann M., Kraft T., Pahlke D., Reinhardt J., Thoms H., 2007: SeisComp3 - automatic and interactive real time data processing. Geophysical Research Abstracts In EGU General Assembly, 9, 09129.

ZAMG - Zentralanstalt für Meterologie und Geodynamik, 1987: Austrian Seismic Network. International Federation of Digital Seismograph Networks, Other/Seismic Network, doi : 10.7914/SN/OE. 